\title{
Quantitative variations of taxifolin and its glucoside in Pinus sylvestris needles consumed by Diprion pini larvae
}

\author{
MA Auger ${ }^{1}, \mathrm{C}$ Jay-Allemand 2, C Bastien 2, C Geri ${ }^{1}$ \\ 1 INRA, Station de Zoologie Forestière; \\ 2 INRA, Station d'Amélioration des Arbres Forestiers, F-45160 Ardon, France
}

(Received 22 March 1993; accepted 2 November 1993)

\begin{abstract}
Summary - The relationships between quantitative variations of 2 flavanonols in Scots pine needles and Diprion pini larvae mortality were studied. Those 2 compounds were characterized as taxifolin (T) and its glucoside (TG) after hydrolysis and analysis by TLC, HPLC and spectrophotometry. Quantitative differences between 30 clones were more important for TG than for $T$, nevertheless clones which presented a content of taxifolin higher than $1.5 \mathrm{mg} \mathrm{g}^{-1} \mathrm{DW}$ showed a T/TG ratio equal to or greater than 0.5 (fig 2). Quantitative changes were also observed throughout the year. The amount of taxifolin peaked in autumn as those of its glucoside decreased (fig 3). Darkness also induced a gradual increase of T but no significant effect on TG (fig 4). Storage of twigs during feeding tests and insect defoliation both induced a strong glucosilation of taxifolin in needles (table 1). High rates of mortality of Diprion pini larvae were associated with the presence of $T$ and TG both in needles and faeces (table II). Preliminary experiments of feeding bioassay with needles supplemented by taxifolin showed a significant reduction of larval development but no direct effect on larval mortality (table III). Regulation processes between taxifolin and its glucoside, which could involve glucosidases and/or transferases, are discussed for the genetic and environmental factors studied.
\end{abstract}

Pinus sylvestris / Diprion pini / larvae / taxifolin / taxifolin glucoside

Résumé - Variations quantitatives de la taxifoline et de son glucoside dans les aiguilles de Pinus sylvestris consommées par les larves de Diprion pini L. Les relations entre le contenu des aiguilles de pin sylvestre en flavanonols et la mortalité larvaire de $\mathrm{D}$ pini ont été étudiées. Les variations quantitatives de 2 composés, caractérisés comme étant la taxifoline $(T)$ et un glucoside de taxifoline (TG), ont été observées en fonction de différents facteurs. De fortes différences quantitatives ont été observées sur le contenu en TG de 30 clones (fig 2). L'évolution du contenu des aiguilles en $T$ et TG au cours d'une année se caractérise, en particulier, par de fortes teneurs en $T$ en automne (fig 3). De même, l'effet de l'obscurité sur les rameaux provoque une

Abbreviations: T: taxifolin; TG: taxifolin glucoside; DMACA: dimethylaminocinnamaldehyde; HPLC: high performance liquid chromatography; TLC: thin layer chromatography; UV: ultraviolet; DW: dry weight; d: day. 
augmentation de la forme aglycone (fig 4). Le stockage des rameaux durant les tests d'alimentation des larves ou bien l'impact de défeuillaisons (artificielles ou naturelles) entraînent une forte augmentation du glucoside (tableau 1). La présence de ces flavanonols est liée à la mortalité des larves (tableau II). Les premières expériences de tests biologiques réalisées avec du feuillage supplémenté en taxifoline montrent une réduction significative du développement larvaire mais pas d'effet sur la mortalité (tableau III). Les processus de régulation entre les 2 formes ( $T$ et $T G$ ), pouvant faire intervenir des glucosidases et/ou des transférases, sont discutés en relation avec les différents facteurs étudiés.

Pinus sylvestris / Diprion pini / larve / taxifoline / taxifoline glucoside

\section{INTRODUCTION}

Natural resistance of forest trees to insect pests is an important adaptive trait in breeding strategies. Whereas numerous biochemical studies on insect-plant relationships have been conducted (Harborne, 1985), few markers of selection are used in breeding programmes and the chemical mechanisms involved in these relationships remain poorly known (Berryman, 1988). These compounds have been used in genetics of the genus Pinus to distinguish species, ecotypes and clones (Thielges, 1972; Laracine-Pittet and Lebreton, 1988). In Pinus sylvestris, several families of phenolic compounds were characterized (Popoff and Theander, 1977; Niemann, 1979). Different chemomorphs were determined with flavonoids including quantitative variations of flavonols and proanthocyanidins (Laracine-Pittet and Lebreton, 1988) and the absence or presence of taxifolin and its inheritance were studied (Lebreton et al, 1990; Yazdani and Lebreton, 1991). Furthermore, toxic effects of different clones against insect attacks have been related to the polyphenolic content of the foliage (Thielges, 1968). Indeed, phenolic compounds are often involved in defence mechanisms (Lunderstädt, 1976; Harborne, 1985) and can be regulated by enzymes (Rhodes and Wooltorton, 1978). Various flavonoids are particularly known to confer resistance towards insect attack in several plant species (Elliger et al, 1980; Schopf, 1986). The presence of 2 typical flavonoids in Scots pine needles (characterized by thin layer chromatography (TLC)) was linked to high rates of larvae mortality of Diprion pini (Hymenoptera, Diprionidae) (Auger et al, 1991).

Before progressing in the knowledge of these host-insect interactions, these 2 compounds (F1 and F2) have to be identified. This is the first step of the study presented here. Therefore, to examine the potential toxicity of the 2 flavonoids against the pine sawfly, Diprion pini, quantitative variations of $F 1$ and $F 2$ were estimated for both clonal and seasonal factors. The study of needle edibility by Diprion pinilarvae was based on feeding tests using cut twigs replaced every $3 \mathrm{~d}$ (Auger et al, 1990). The effects of this bioassay technique both associated and unassociated with mechanical defoliation were studied through flavonoid contents, and then compared with incidence of larval defoliation. Furthermore, needles supplemented by taxifolin were used to study the effect of this phenolic compound on the development of young larvae of Diprion pini.

\section{MATERIALS AND METHODS}

\section{Plant material and feeding bioassay methods}

Different clones (37) of Scots pine from 2 natural provenances used as breeding populations in 
INRA breeding programme conducted at Orléans station were used in the following experiments. Four clones ( $N^{\circ} 733,847,864$ and 875 ) belong to the French natural provenance Haguenau (Alsace) and 33 clones ( $N^{\circ} 627,646,649$, etc) belong to the Polish natural provenance Taborz (Mazurie). Each clone, identified by a code number, is represented by several grafted copies planted in 2 clonal archives Orléans (Loiret) and Cadouin (Dordogne).

\section{Experiment 1}

Interclonal variations were studied on 30 clones from Taborz population collected in May 1991 from the Cadouin collection grafted in 1981. Each clone was represented by 5 grafted copies and each sample was composed of 25 needles formed in 1990 (5 needles of each copy).

\section{Experiment 2}

Endogenous changes ( $F 1$ and $F 2$ ) in needles of 2 grafted trees of 2 clones located in Orléans collection (847, tree $1 ; 646$, tree 2) were analysed throughout the year (June 1989 to June 1990) from samples collected in the middle of every month. Each sample was composed of 50 needles which were collected at random in the same trees.

\section{Experiment 3}

In order to compare seasonal effect to darkness effect, terminal shoots of 2 grafted trees of 2 clones (847, tree $3 ; 864$, tree 4 ) were bagged in May 1991 with special material (black inside and white outside) for $30 \mathrm{~d}$. Needles were collected at the beginning of the experiment and after 15 and $30 \mathrm{~d}$. Each sample consisted of 20 needles and all samples from each clone were always collected in the same bag. Biological test modalities are described by Auger et al, 1990.

\section{Experiment 4}

Storage and insect-like defoliation effects were observed in April 1991 on terminal cut shoots of 2 clones, 627 and 649 of Orléans collection which contained the compounds $\mathrm{F} 1$ and $\mathrm{F} 2$. After $3 \mathrm{~d}$ the wounding response of needles half cut mecha- nically and storage stress of these cut shoots were studied. Each sample consisted of 15 needles. For half-cut needles, $1 \mathrm{~cm}$ of each needle was collected from the border of the wounded zone.

\section{Experiment 5}

Feeding bioassays were performed in February 1990 with first instar larvae reared in growth chamber $\left(15.30 / 8.30 \mathrm{~h}\right.$ photoperiod, $16^{\circ} \mathrm{C}$ temperature). Larvae were fed with 4 clones (627 and 649 with $F 1$ and $F 2 ; 733$ and 875 without $F 1$ and F2) for $12 \mathrm{~d}$ (foliage was removed and replaced every 3 d) (fig 1). Larval mortality rates were determined at the end of the test. Needles with and without larval damage (10 per sample) were collected at the second foliage change to estimate the insect impact on polyphenolic content. Faeces produced during the all tests were also collected for phenolic analysis.

\section{Experiment 6}

In August 1992, first instar larvae were fed with needles from one clone $(733$, without $F 1$ and $F 2$, favourable to the survival and the development of $D$ pinilarvae) for $12 d$. Two series of shoots were used in this experiment: one series was sprayed by a solution $\left(10^{-2} \mathrm{M}\right.$ ) of standard taxifolin (Extrasynthèse, France) while the other (control) was not supplemented by taxifolin. After $12 \mathrm{~d}$, larval survival rates and percentage of larvae that had reached the third instar were determined.

\section{Biochemical methods}

All needles or faeces samples were frozen immediately after collection in liquid nitrogen and then freeze-dried and ground to a powder before storage in dry conditions under vacuum

\section{Extraction}

Polyphenols were extracted from $50 \mathrm{mg}$ of dry matter in $2.2 \mathrm{ml}$ methanol $80 \%$ containing $0.1 \%$ sodium metabisulfite (antioxidant) and $200 \mu \mathrm{l}$ methoxyflavon (internal standard at $10^{-3} \mathrm{M}$ ), for $30 \mathrm{~min}$ by sonication. The extract was then fil- 


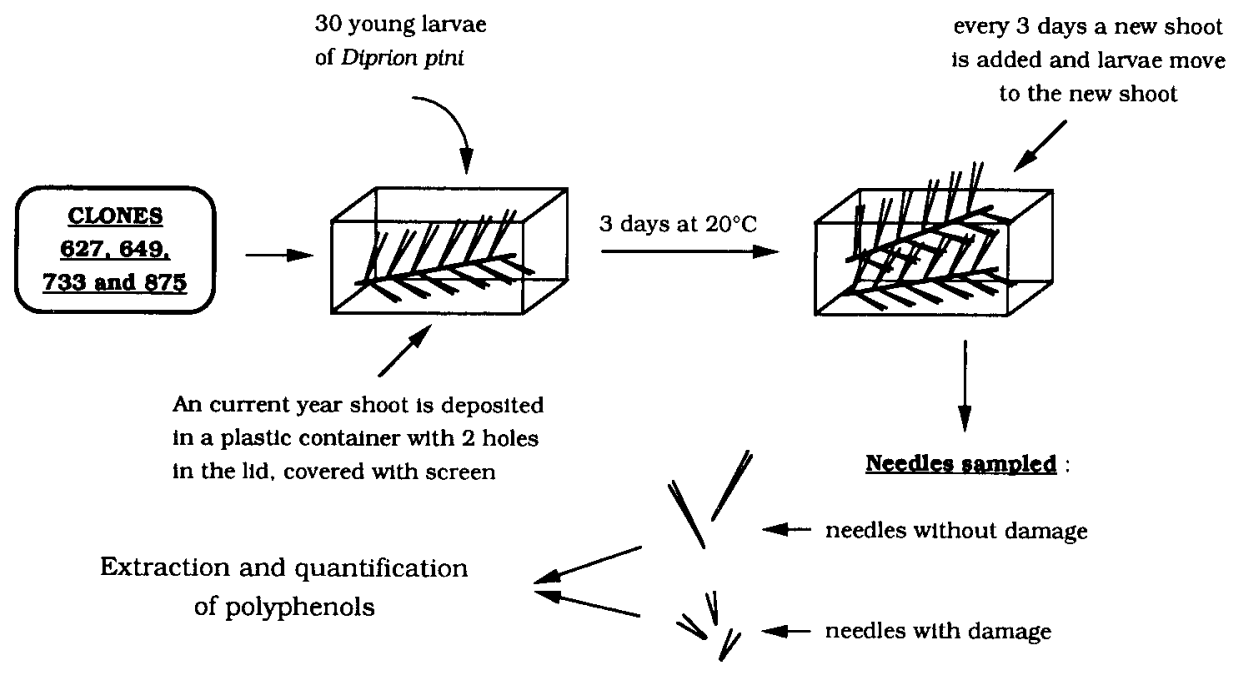

Fig 1. Description of the feeding test of larvae of Diprion pini with fresh twigs of Pinus sylvestris. Shoots were renewed in the plastic container every $3 \mathrm{~d}$ and intact or damaged needles were sampled for the biochemical analyses.

tered in a Büchner tunnel and the filter paper and phial were rinsed with $2 \mathrm{ml}$ methanol $80 \%$ and $500 \mu$ pure methanol, respectively. The whole extract was dried in a speed-vac and the residue was diluted in $500 \mu \mathrm{l}$ pure methanol; $20 \mu \mathrm{l}$ of this final extract were analysed by means of HPLC.

The coefficient of variation of the extraction, separation (HPLC) and measure procedure (integration and quantification of T and TG) for 6 independent replicates ( 6 extracts from the same powder) was less than $3 \%$.

\section{Elution programme}

Polyphenol separation and quantification were conducted from the following conditions: column, lichrospher $5 \mu \mathrm{m} 100 \mathrm{RP}-18250 \times 4 \mathrm{~mm}$; solvent $A=$ water/acetic acid $1 \%$ and solvent $B=$ methanol/butanol $5: 1 \mathrm{v} / \mathrm{v}$; elution gradient $10 \%$ $B$ in $A$ for $2 \mathrm{~min}, 10-15 \%$ B in $A$ for 8 min, $15 \%$ B in $A$ for $8 \mathrm{~min}, 15-20 \% \mathrm{~B}$ in $A$ for $4 \mathrm{~min}, 20-100 \%$ $B$ in $A$ for $13 \mathrm{~min}, 100 \%$ B for $7 \mathrm{~min}$; flow $1 \mathrm{ml} / \mathrm{min}$; UV detection at $280 \mathrm{~nm}$. Each compound was characterized by its retention time and UV spectrum determined between 250 and $350 \mathrm{~nm}$.

\section{Identification}

Concentrated fractions were collected after separation in HPLC or after passing through a polyamide column. Acid hydrolysis of these fractions was conducted in boiled $2 \mathrm{~N}$ hydrochloric acid for $30 \mathrm{~min}$. Enzymatic hydrolysis applied on the same products was conducted with $\beta$-glucosidase (Sigma) according to the method described by Marcinowski and Grisebach (1978), to determine the sugar of the glycoside. Products obtained after hydrolysis were analysed by TLC, HPLC and spectrophotometry. First, they were separated in TLC (DC-Alufolien cellulose) in 1 dimension with methyl sobutyl cetone/formic acid/water, $3: 1: 2, v / v / v$ (upper phase) to identify the aglycon part of the above molecule. After migration, observations were made under UV light and compared with standard taxifolin and the TLC experiment was sprayed with Pew reagent $(\mathrm{Zinc} / \mathrm{HCl})$, specific to the flavanonols family (Grayer, 1989). To identiiy the glycoside molecule, a spectral analysis was made after adding $\mathrm{AlCl}_{3}$ or $\mathrm{NaOH}$ (Markham, 1982), and the TLC experiment was sprayed before hydrolysis with Benedickt reagent (orthodiphenol extinction and stronger monophenol fluorescence). The hydrolysis products were analysed by co-chromatography with standard glucose and by co-chromatography in HPLC 
with commercial taxifolin and their UV spectra were compared.

\section{Spraying of standard taxifolin on pine shoots}

A solution of standard taxifolin $10^{-2} \mathrm{M}$ in acetone $(20 \mathrm{ml})$ was sprayed with a small sprayer machine onto the pine shoots. When the solvent had evaporated, shoots were used to feed the larvae and removed every $3 \mathrm{~d}$.

\section{RESULTS}

\section{Identification of the 2 phenolic compounds}

Compound F2 was characterised as a flavanonol (spraying with Pew reagent) and specifically as taxifolin ( $T$, dihydroquercetin) by co-chromatography on TLC $\left(R_{\mathrm{f}} 1 \mathrm{D}\right.$ : $0.87)$ fluorescing yellow to brownish and HPLC (retention time: $17 \mathrm{~min}$ ) with commercial taxifolin. In addition, these $2 \mathrm{com}-$ pounds were stained on a cellulose TLC plate by DMACA reagent as blue-grey spots (Auger et al, 1991). The UV spectrum of $\mathrm{F} 1$ resembled that of authentic taxifolin showing a maximum at $286 \mathrm{~nm}$ and a shoulder at $310 \mathrm{~nm}$ indicating the structural relationship of the 2 compounds. After acid hydrolysis, the aglycon was identified as taxifolin by co-chromatography (TLC) with an authentic sample. The enzymatic hydrolysis with $\beta$-glucosidase released glucose (co-chromatography with standard glucose and HPLC analysis). It was also proved that F 1 was not hydrolysed without enzyme and spectral analysis showed that the positions 5 and 7 were free. The analysis by TLC after spraying Benedickt reagent also proved that the position of the sugar was probably $3^{\prime}$ or $4^{\prime}$. From these findings, it was deduced that $\mathrm{F} 1$ was a $\beta$-O-glucoside of taxifolin.

\section{Experiment 1}

From needles of the 30 clones of Scots pine collected in May 1991, T and TG were absent from about 1 out of 3 clones. When the 2 flavanonols were present, intraclonal standard deviations were 1.37 and 0.58 for TG (mean 3.61) and T (mean 1.14), respectively. Thus, quantitative variations between clones were more important for $T$ than for TG (fig 2). A ratio T/TG superior or about 0.5 was observed on the clones with a content of $\mathrm{T}$ higher than $1.5 \mathrm{mg} \mathrm{g}^{-1} \mathrm{DW}$ only.

\section{Experiments 2 and 3}

An increase of $\mathrm{T}\left(5-7.5 \mathrm{mg} \mathrm{g}^{-1} \mathrm{DW}\right)$ was found in autumn period for the 2 trees studied in needles formed either in the spring of 1988 or 1989 . All these samples were collected from June 1989 to June 1990. In June, the $\mathrm{T}$ amount was about $2 \mathrm{mg} \mathrm{g}^{-1}$ DW. Moreover, the evolution of the 2 flavanonols showed typical phases, while the $T$ accumulated in the autumn, the amount of its glucoside decreased (fig 3). Furthermore, between June and August, the average amount of taxifolin in needles of currentyear foliage wes 1.5- or 2.5-fold higher than in needles of 1-yr-old foliage (Tree $1 \mathrm{~F} 88$ : $1.8 \mathrm{mg} \mathrm{g}^{-1} \mathrm{DW}$; Tree 1 F89: $4.3 \mathrm{mg} \mathrm{g}^{-1} \mathrm{DW}$; Tree 2 F88: $2.15 \mathrm{mg} \mathrm{g}^{-1}$ DW; Tree 2 F89: $\left.3.1 \mathrm{mg} \mathrm{g}^{-1} \mathrm{DW}\right)$.

In experiment 3 , darkness also induced a gradual increase of $T$ in needles of trees 3 and 4 (fig 4) whereas no significant effect was observed on amount of TG.

\section{Experiment 4}

A storage effect during $3 \mathrm{~d}$ induced a severe decrease of $T$ and a correlated increase of TG (table I). An additional important decrease of $T$ was observed for both clones 

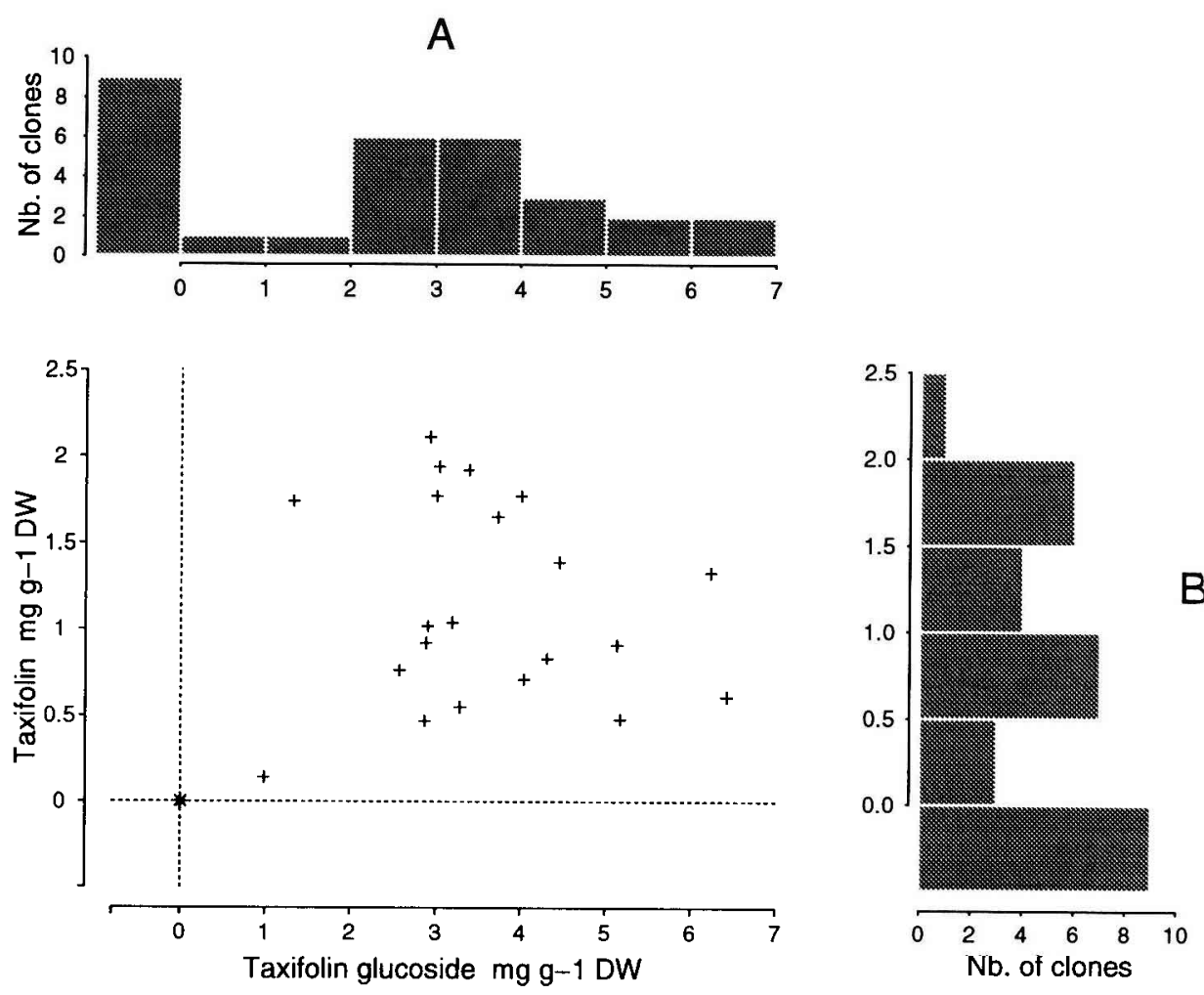

Fig 2. Qualitative and quantitative variations of flavanonols ( $T$ and $T G$ ) in 30 clones of Pinus sylvestris which are determined from needles collected in May 91 . * 9 clones without $T$ and $T G$, which are represented by the first class of each histogram; A: histogram of the mean clonal amount of TG; B: histogram of the mean clonal amount of T.

in the presence of mechanical defoliation whereas a significant increase of TG of $26 \%$ was noticed for clone 649 only.

\section{Experiment 5}

Insect defoliation for $3 \mathrm{~d}$ induced a strong glucosilation of $T$ in needles (wounded zone) of the 2 clones studied (table I). High rates of larval mortality, which were fed $9 \mathrm{~d}$, were associated with the presence of $T$ and $T G$, found in both needles and faeces (table II).
Clone 627 was richer in total amount of the 2 phenols than clone 649 , although feeding of the latter resulted in a higher larval mortality.

\section{Experiment 6}

The amount of taxifolin extracted from the needles sprayed with authentic $T$ was analysed by HPLC and was about $3 \mathrm{mg} \mathrm{g}^{-1}$ DW. However, no difference in larval survival rates were observed between the 2 


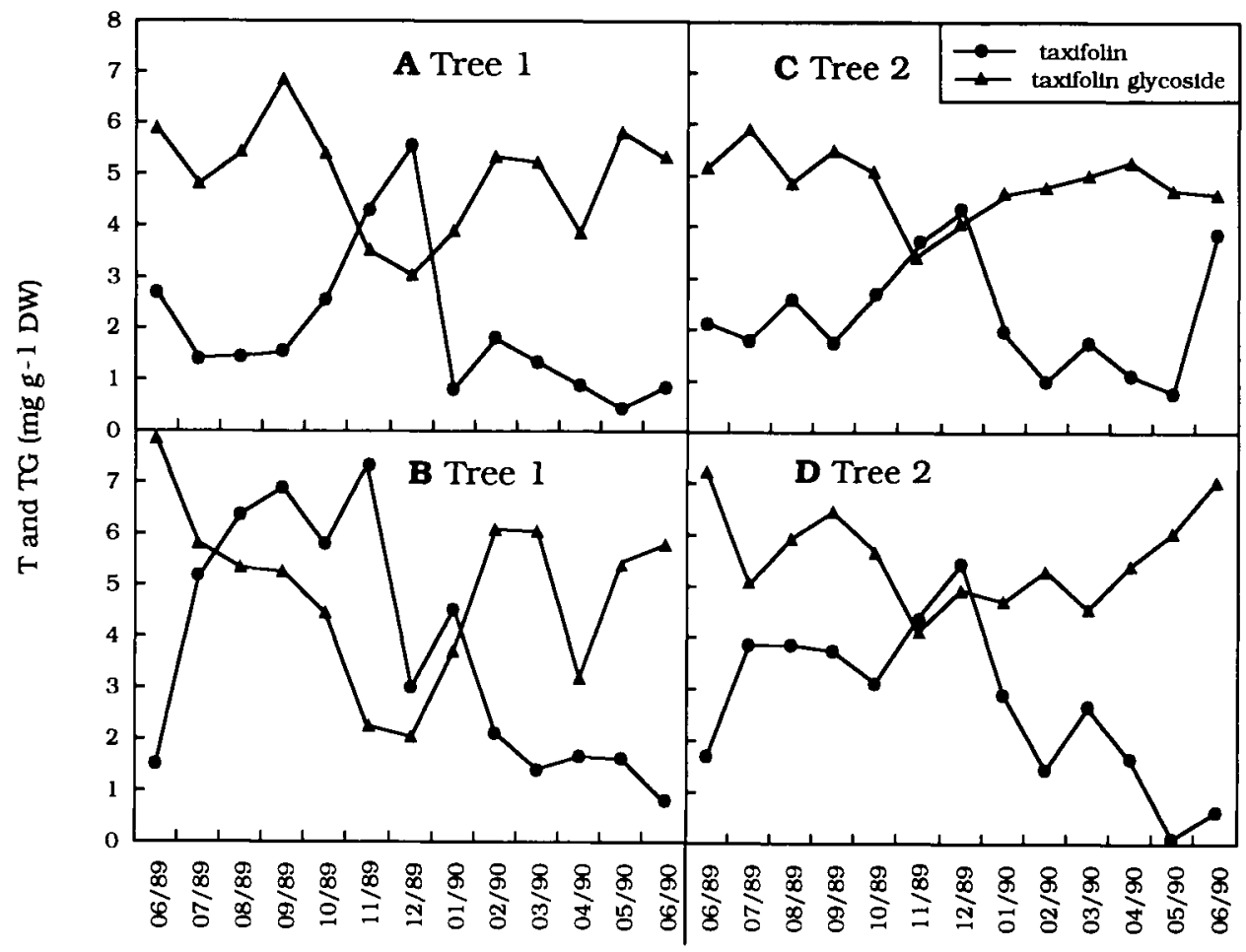

Date

Fig 3. Seasonal evolution of T and TG contents in needles of 2 trees of Pinus sylvestris. A and B, tree 1 corresponding to clone $847 ; C$ and $D$, tree 2 corresponding to clone $646 ; A$ and $C$, samples formed in 1988; B and D, samples formed in 1989.

series (larvae fed with control shoots or with sprayed shoots). But, the larval development was strongly reduced when larvae were fed with sprayed needles (table III).

\section{DISCUSSION AND CONCLUSIONS}

The 2 previously studied compounds $F 1$ and $\mathrm{F} 2$ were identified as $\mathrm{T}$ and $\mathrm{TG}$ by means of TLC, co-chromatography in HPLC, and acid and enzymatic hydrolysis. Indeed, these compounds have previously been identified in leaves of Pinus sylvestris
(Popoff and Theander, 1977; Niemann, 1979; Laracine-Pittet and Lebreton, 1988; Lungren and Theander, 1988). Moreover, these flavanonols were not present in all clones of this species (Lebreton et al, 1990; Auger et al, 1991) (fig 2). Among the 30 Polish clones tested, $2 / 3$ were marked by the presence of these compounds. By crossing experiments, Yazdani and Lebreton (1991) have shown that clones with $T$ are all regarded as heterozygotes $T t$ and that homozygotes TT are probably rare in the population. In our population, clonal variability also exists for quantitative amount 

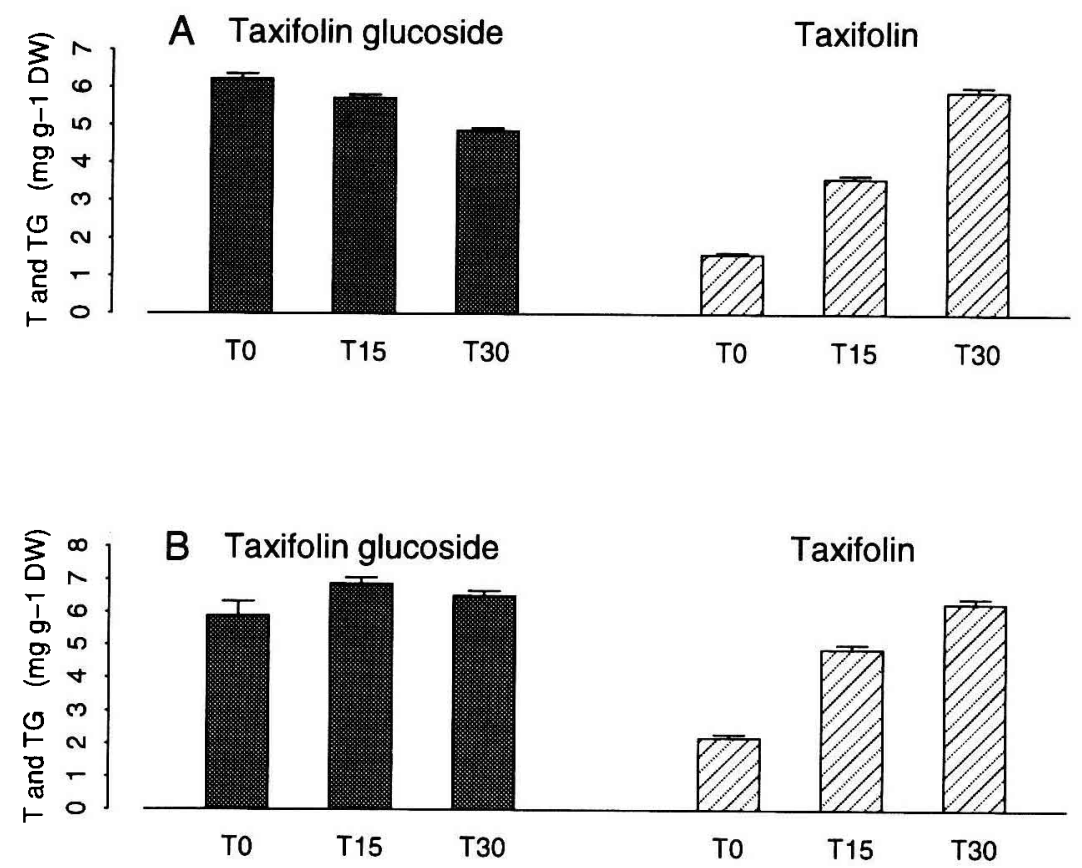

Fig 4. Effect of darkness, applied during 15 (T15) and 30 (T30) d, on taxifolin ( $\square$ ) and its glucoside ( contents in Pinus sylvestris. A, tree 3 corresponding to clone 847; B, tree 4 corresponding to clone 864 . SE are calculated from 2 replicates.

Table I. Effects of storage (April 1991) and mechanical defoliation after $3 \mathrm{~d}$ in experiment 4 (A) and effect of Diprion pini larvae attacks (February 1990) after $3 d$ in experiment 5 (B), on T and TG contents in needles (in $\mathrm{mg} \mathrm{g}^{-1} \mathrm{DW}$ ).

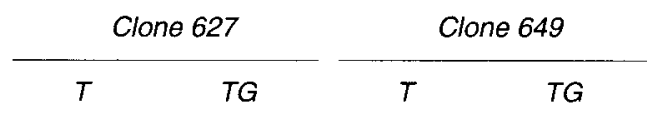

A

To (intact twigs)

$4.53 \pm 0.12 \quad 4.87 \pm 0.18 \quad 3.83 \pm 0.10 \quad 3.18 \pm 0.12$

T3 (intact twigs after storage)

$1.67 \pm 0.04 \quad 9.21 \pm 0.35 \quad 1.88 \pm 0.05 \quad 6.83 \pm 0.26$

T3 (mechanical defoliated twigs after storage) $0.30 \pm 0.01 \quad 9.62 \pm 0.36 \quad 0.38 \pm 0.01 \quad 8.61 \pm 0.33$

B

T3 (needles without larval damage)

$7.02 \pm 0.19 \quad 0.22 \pm 0.01 \quad 3.36 \pm 0.09 \quad 0.20 \pm 0.01$

T3 (needles with larval damage)

$0.24 \pm 0.01 \quad 6.93 \pm 0.26 \quad 0.17 \pm 0.01 \quad 3.67 \pm 0.14$

Data are the mean \pm SE of 3 replicates. 
Table II. Biological tests made on 4 clones of Pinus sylvestris. Larvae of Diprion pini were fed with needles for $9 \mathrm{~d}(3 \times 3)$. *

\begin{tabular}{lcccc}
\hline & & & Clones & \\
& 733 & 875 & 627 & 649 \\
\hline Mortality rates (\%) & $25 \pm 5.0$ & $34.7 \pm 1.9$ & $64.3 \pm 11.0$ & $96.2 \pm 3.8$ \\
$T+\mathrm{TG}$ in needles $\mathrm{mg} \mathrm{g}^{-1} \mathrm{DW}$ & 0 & 0 & 7.2 & 3.6 \\
$T+\mathrm{TG}$ in faeces $\mathrm{mg} \mathrm{g}^{-1} \mathrm{DW}$ & 0 & 0 & 9.6 & 4.9 \\
\hline
\end{tabular}

* Mortality rates and flavanonol content ( $T$ and $T G$ ) were determined. Biochemical analyses were made on needles used in the test and on faeces of larvae collected at the end of the test. Data for mortality rates are the mean \pm SE of $5-7$ replicates. Biochemical analyses were made on needles used in the test and on faeces of larvae collected at the end of the test.

Table III. Biological test made on one clone (without T and TG) of Pinus sylvestris. *

\% larval mortality $\quad \%$ 3rd instar larvae (L3)

$\begin{array}{lll}\text { Control shoots } & 11.7 \pm 1.7 & 37.6 \pm 6.8 \\ \text { Shoots sprayed with taxifolin } 10^{-2} \mathrm{M} & 18.3 \pm 1.7 & 22.4 \pm 1.6\end{array}$

* Larvae of Diprion pini were fed with 2 series of needles for $12 \mathrm{~d}(3 \times 4)$ : one series (control) was not supplemented by $T$ and the other was sprayed by a solution $\left(10^{-2} \mathrm{M}\right)$ of standard $\mathrm{T}$. Larval mortality and development rates (\% of third instar larvae) were determined at the end of the test. Data are the means \pm SE of 2 replicates.

of $T$ and $T G$.

Quantitative changes of the 2 compounds throughout the year showed a similar pattern for 2 trees corresponding to 2 different clones. We showed that $T$ increased markedly in autumn, whereas the amounts of $T G$ decreased. Thus, this high accumulation of $T$ in needles could be explained by either an enzymatic hydrolysis of TG by a $\beta$-glucosidase or a reduction of the glucosyl-transferase activity during this period, provided no modification occurs in the direct synthesis of T. Comparable studies on seasonal evolu- tion often concerned the total amount of phenols: In autumn, a gradual increase of jack pine foliage polyphenols was also observed by Nozzolillo et al (1989). Moreover, the anthocyanin contents increased rapidly at earlier rather than later stages of Polygonium seedlings in all growing seasons (Miura and Iwata, 1982). Seasonal changes of phenols were observed in the leaves of Quercus petraea (Beres, 1984). In Pinus sylvestris, the effect of darkness on T was similar to that observed in autumn, when daylight decreases; a great increase was rapidly seen after dark treatment. The 
absence of a significant change of TG content could rather explain that this accumulation of $T$ results in a de novo synthesis and/or in a limitation of the glucosilation process. Light intensity and darkness are known to influence phenolic metabolism and to modify the phenolic contents (Beres, 1980; Contour-Ansel and Louguet, 1985). In addition, it was shown that current-year foliage has a toxic effect on Diprion pini larvae (Geri et al, 1985). These results could be related to the strong accumulation of $T$ found in these young needles in June to August (fig 4).

The potential toxicity of the 2 flavonoids against Diprion pini was assessed through biological tests. Mechanical defoliation of twigs used in these tests induced mainly a decrease of T. Wagner and Evans (1985) showed that the accumulation of total phenols was higher in ponderosa pine seedlings when the trees were mechanically defoliated. In addition, quantitative variations of polyphenols in foliage, growing after artificial defoliation, has been demonstrated in Populus tremuloides by Mattson and Palmer (1988).

Moreover, modifications observed in needles attacked by Diprion pini were accompanied by an increase of TG, which could be explained by an activation of a glucosyl-transferase activity. Attacks by insects resulted in modifications of the metabolism of polyphenols (Wagner, 1988). Indeed, Thielges (1968) noticed an increase of phenolic compounds in Pinus sylvestris needles which was induced by a Neodiprion sertifer attack, but no information was given concerning the nature of the phenolic compounds involved.

The results of our biological tests were linked to the presence or the absence of $T$ and TG: $70 \%$ of the clones containing the 2 compounds were unfavourable to the survival of Diprion pini larvae (Auger et al, 1991). T was previously known to have an antigrowth activity towards insects (Elliger et al, 1980). When the aglycon was sprayed on the foliage, larval development rates were lower. There was no difference between larval survival rates when the insects were fed with shoots without $T$ or with shoots sprayed with $T$. However, this feeding bioassay was preliminary and no experiments were made with the TG (there is still no authentic TG). Dreyer and Jones (1981) showed a biological activity of the flavanone aglycons against the aphid Schizaphis graminum although the flavanone glucosides appeared to be inactive. Larsson et al (1992) observed no or few differences in the development rates of Neodiprion sertifer and $D$ pini larvae fed with pine with or without TG. However, survival rates of $D$ pini larvae, even diapause rates were not observed and the presence or absence of the aglycon was not studied. But, in our case, the total amount in these flavanonols compared between the clones 627 and 649 was not correlated to the toxic effect, suggesting that the main factor involved in this toxicity phenomena could be the proportion and/or the speed of transformation between $T$ and TG rather than the total amount of flavanonols ( $T$ and $T G$ ) found in needles or faeces.

Therefore, whereas the aglycon form is known to be the most active, it seems that the enzymatic regulation in needles between the 2 forms ( $T$ and $T G$ ) could play a major role in the resistance of several pine clones towards Diprion attacks, depending on clonal and environmental factors.

\section{ACKNOWLEDGMENTS}

We would like to thank M Loonis (INRA, Avignon) for her help in identifying the glucoside, $J$ Turgeon and $\mathrm{D}$ Treutter for the correction of this article. This research was part of the 'Relations pin sylvestre-insectes' project funded by ARBOCENTRE, Association pour la Recherche sur la Production Forestière et le Bois en Région Centre.

\section{REFERENCES}


Auger MA, Geri C, Jay-Allemand C, Bastien C (1990) Comestibilité du feuillage de différents clones de pin sylvestre par Diprion pini $\mathrm{L}$ (Hym Diprionidae). I. Incidence de la consommation des aiguilles de différents clones de pin sylvestre sur le développement de $D$ pini $\mathrm{L}$. $J$ Appl Ent 110, 489-500

Auger MA, Jay-Allemand C, Bastien C, Geri C (1991) Comestibilité du feuillage de différents clones de pin sylvestre par Diprion pini L ( Hym Diprionidae). II. Relations entre le contenu phénolique des aiguilles et la mortalité des larves. J Appl Ent 111, 78-85

Beres $C$ (1980) Seasonal changes in the reducing organic materials of shrub leaves. Acta Bot Acad Sci Hung 26, 247-254

Beres $C$ (1984) Phenol and non-structural carbohydrate contents in the leaves of Quercus petraea. Acta Bot Hung 30, 247-254

Beres C (1984) Phenol and non-structural carbohydrate contents in the leaves of Quercus petraea. Acta Bot Hung 30, 461-467

Berryman AA (1988) Toward a unified theory of plant defense. In: Mechanisms of Woody Plant Defenses against Insects (WJ Mattson, J Levieux, C Bernard-Dagan, ed). Springer Verlag, New-York, 39-55

Contour-Ansel D, Louguet P (1985) Short-term effect of light on phenolic compounds in isolated leaf epidermis of Pelargonium $\times$ hortorum. J Plant Physiol 120, 223-231

Dreyer DL, Jones KC (1981) Feeding deterrency of flavonoids and related phenolics towards Schizaphis graminum and Myzus persicae: Aphid feeding deterrents in wheat. Phytochemistry 20, 11, 2489-2493

Elliger CA, Chan BG, Waiss AC (1980) Flavonoids as larval growth inhibitors. Naturwiss 67, 358-360

Geri C, Allais JP, Goussard F, Liger A, Yart A (1985) Incidence de l'âge du feuillage sur le développement de Diprion pini L (Hym, Diprionidae). Conséquences sur l'évolution des populations. Acta Oecol, Oecol Appl 6 (4), 349-365

Grayer RJ (1989) Flavanoids: In: Methods in Plant Biochemistry (PM Dey, JB Harborne, ed) Academic Press London, 1, 283-323

Harborne JB (1985) Phenolics and plant defense. In: The Biochemistry of Plant Phenolics (CF
Van Sumere, PJ Lea, ed) Clarendon Press, and Ann Proc Phyto Soc Eur, Oxford, 25, 393408

Laracine-Pittet C, Lebreton P (1988) Flavonoid variability within Pinus sylvestris. Phytochemistry 27, 2663-2666

Larsson S, Lundgren L, Ohmart CP, Gref R (1992) Weak responses of pine sawfly larvae to high needle flavonoid concentrations in Scots pine. J Chem Ecol 18, 271-282

Lebreton P, Laracine-Pittet C, Lauranson J (1990) Variabilité polyphénolique et systématique du pin sylvestre Pinus sylvestris L. Ann Sci For $47,117-130$

Lunderstädt $J(1976)$ Isolation and analysis of plant phenolics from foliage in relation to species characterization and to resistance against insects and pathogens. In Modern Methods For Genetics (JP Miksche, ed). Springer-Verlag, Berlin, 158-164

Lungren LN, Theander O (1988) Cis-and transdihydroquercetin glucosides from needles of Pinus sylvestris. Phytochemistry 27, 829-832

Marcinowski S, Grisebach H (1978) Enzymology of lignification cell-wall-bound. $\beta$-glucosidase for coniferin from spruce (Picea abies) seedlings. Eur J Biochem 87, 37-44

Markham KR (1982) Techniques of Flavonoid Identification. Academic Press, London

Mattson WJ, Palmer SR (1988) Changes in levels of foliar minerals and phenolics in trembling aspen, Populus tremuloïdes, in response to artificial defoliation. In: Mechanisms of Woody Plant Defenses against Insects (WJ Mattson, J Levieux, C Bernard-Dagan, ed). Springer Verlag, New York, 157-169

Miura H, Iwata M (1982) Effect of growing seasons on anthocyanin content of seedlings of benitate (Polygonium hydropiper L). J Jpn Soc Hort Sci 51, 2, 165-171

Niemann GJ (1979) Some aspects of the chemistry of pinaceae needles. Acta Bot Neerl $28,1,73-88$

Nozzolillo C, Isabelle P, Das G (1989) Seasonal changes in the phenolic constituents of jack pine seedlings (Pinus banksiana) in relation to the purpling phenomenon. Can J Bot 68 , 2010-2017

Popoff T, Theander O (1977) The constituents of conifer needles. VI. Phenolic glycosides from Pinus sylvestris. Acta Chem Scand B 31 4, 329-337 
Rhodes JM, Wooltorton LSC (1978) The biosynthesis of phenolic compounds in wounded plant storage tissues. In: Biochemistry of Wounded Plant Tissues (G Kahl, ed). De Gruyter, Berlin, 243-286

Schopf R (1986) The effect of secondary needle compounds on the development of phytophagous insects. For Ecol Manag 15, 55-64

Thielges BA (1968) Altered plyphenol metabolism in the foliage of Pinus sylvestris associated with European pine sawfly attack. Can $J$ Bot 46, 724-725

Thielges BA (1972) Intraspecific variation in foliage polyphenols of Pinus (subsection syl- vestres). Silvae Genetica 21, 3-4

Wagner MR (1988) Influence of moisture stress and induced resistance in Ponderosa pine, Pinus ponderosa Dougl ex Laws, on the pine sawtly. Neodiprion autumnalis. Smith, For Ecol Manag 15, 43-53

Wagner MR, Evans PD (1985) Defoliation increases nutritional quality and allelochemics of pine seedlings. Oecologia 67, 235-237

Yazdani R, Lebreton P (1991) Inheritance pattern of the flavonic compounds in Scots pine (Pinus sylvestris L). Silvae Genetica 40, 2, 57-59 